(平成 9 年 3 月 12 日受理)

パワーネット布の二軸伸長特性予測へのリニアライジング法の応用

奈良女子大学 稲村綾子・丹羽雅子

\title{
Applications of the Linearizing Method to Biaxial Extension of Power-net Fabrics
}

\section{Ayako Inamura and Masako Niwa}

Department of Textile and Apparel Science, Nara Women's University, Nara, 630 Japan

\begin{abstract}
In the performance design of power-net fabric having high formative and vibration-proof effects, prediction of extension properties caused by clothing pressure is one of the most important problem. The method of linearizing non-linearlity of a fabric assembly, proposed by S.Kawabata in 1986, has been applied to predict extension property of a power-net fabric having strong anisotropy and non-linearity along the wale and course directions. Optional strain parameters $n_{1}(i=1,2,1$ and 2 are the wale and course directions, respectively) are introduced to transform to stress-strain curves for a linear relation. It is shown that the linearization method is able to estimate stress-strain curves on optional deformation modes from biaxial extension to uniaxial one.
\end{abstract}

(Accepted March 12, 1997)

\section{1. 緒言}

パワーネット布は，弾性条をバック系に用い，ナイロ ンやポリエステルのフロント糸と共に編み立てる 2 また は3枚おさの編み地が主たる構造の㵶維集合体である。 ウェール方向にネットを構成する弾性糸と，それに絡み 付く非弾性系で構成され，この構造体は伸縮性が高く， 形態安定性も比較的よいため，身体に密着して皮䖉の伸 縮に追従するようなファウンデーション，スポーツウェ アなどに広く用いられている，パワーネット布の整形效 果，防振効果，運動機能性は高く評価されているが，着 用時に，布の伸長による身体への圧迫が問題となり，圧 迫力をもたらす布の二朝伸長特性の予測が着用快適性に 関わる性能設幛の上で重要とされる。

布の構造が複雑なため，その二軸伸長特性を構造理論 的に捉えることは困難であるが，現象理論的には，1986 年に開発されたリニアライジング法[1](2)で解析可能と 考えられる，そこで，本研究ではこれを適用し，パワー ネット布の一軸拘束二軸伸長特性から任意の二軸伸長特 性を予測する方法について検討する。

川端によって提案された布状瀻維集合体特有の非線形
性を線形化するリニアライジング法については，今まで に広く織物，編み物に適用可能なことが報告されている が[ 3 ], ウェールとコース方向では大きく異なる性質の 系を使った異方性と非線形性を示すパワーネット布にお けるリニアライジング法の妥当性を確認するために, 械 維素材, 編み組織の異なるパワーネット布を試料として, 実験による検証を行う。

\section{2. リニアライジング法による二軸伸長特性の予測理論}

\section{1 二軸伸長特性の線形化}

Fig.1に示すような直交する2つの構造主軸方向での伸 長变形に扔いて，直交する2つの軸方向にそれぞれ伸長 ひずみ $\varepsilon_{1}, \varepsilon_{2}$ を与え，その時の張力を $F_{1}, F_{2}$ とする。

二軸伸長変形様式は二軸方向の各ひずみ $\varepsilon_{1}, \varepsilon_{2}$ の比 $k_{1}$, k で表すこととする.

$$
\begin{array}{ll}
k_{2}=\varepsilon_{2} / \varepsilon_{1} & \left(\varepsilon_{1} \geqq \varepsilon_{2}\right) \\
k_{1}=\varepsilon_{1} / \varepsilon_{2} & \left(\varepsilon_{1} \leqq \varepsilon_{2}\right)
\end{array}
$$

$$
k_{1}=1 \text { あいは } k_{2}=1 \text { の時, } \varepsilon_{1}=\varepsilon_{2} \text { の均等二軸伸長変形で }
$$

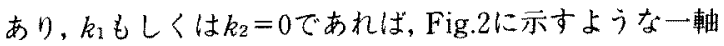
を拘束し，他の軸方向へ伸長变形を与える 2 通りの変形 様式を表わす(以後, 一軸拘束二軸伸長变形之略寸). 


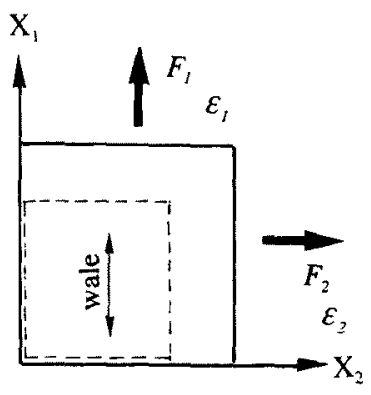

Fig. 1 Biaxial deformation and the coordinate system $\varepsilon$ : strain, $F$ : tensile stress, suffix 1 : wale direction, 2: course direction

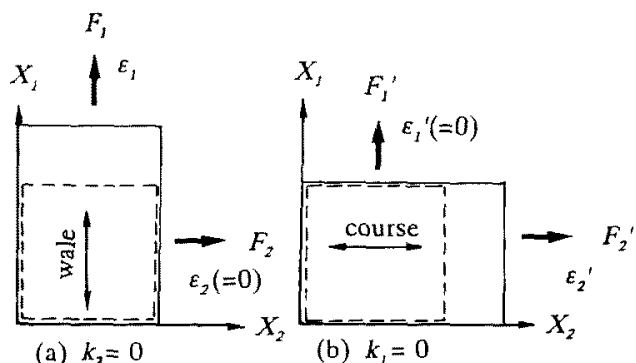

Fig. 2 Strip biaxial deformation (a) along the wale direction under the constant strain for course direction, (b) along the course direction for wale direction.

コ一ス方向を拘束してウェール万向八伸舆する場合と， 逆にウェール方向を拘束してコース方向へ伸長する2つ の一軸拘束二軸伸長変形における張力とUずみを区別す るために，コース方向への一軸拘来三軸伸長変形の張力

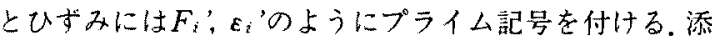
え字1はウエール方向，2はコース方向表す。

繊維集合体の張力ーひずみ関係は，楾形関倸を示さず， ほとんどの場合非線形関係を示す。しかし、これまでの 研究で,ひずみの変換により張力ーUずみ曲線を直線化で きることが経験的に知られている。この非線形性を線形 化するリニアライジング法では、変換ひずみ $e_{i}(i=1,2)$ は 次式によって表される。

$$
e_{i}=\varepsilon_{i}{ }^{n} \quad(i=1,2)
$$

ここで、nは定数で, 布固有の值であり、これまでの多 くの実駼結果に基づき，すへての二軸伸長变形様式にお いて一定であると仮定されている。

\section{2 一軸拘束二軸伸長特性からの任意の二軸变形下て の張力予測}

このような方法で,張力 $F$ と変換ひずみe,の線形関係を 仮定すると，二次元面内の直交二軸伸長に対する線形理
諭から遒がる次式の構成方程式が適用できる。

$$
\left[\begin{array}{l}
e_{1} \\
e_{2}
\end{array}\right]=\left[\begin{array}{ll}
S_{11} & S_{12} \\
S_{21} & S_{22}
\end{array}\right]\left[\begin{array}{l}
F_{1} \\
F_{2}
\end{array}\right]
$$

ここで, $S_{i j}(i, j=1,2) は$, 変換ひずみにより定義された 弾性定数である。材料特性である $S_{i j}$ 仕，2つの一軸拘束 一軸伸長变形下の害測值を張力ー変換ひずみ直線に直し， 次式で決定される。

$$
\begin{aligned}
& S_{11}=1 /\left\{C_{1}\left(1-R_{1} R_{2}\right)\right\} \\
& S_{22}=1 /\left\{C_{2}\left(1-R_{1} R_{2}\right)\right\} \\
& S_{12}=-R_{2} S_{11} \\
& S_{21}=-R_{1} S_{22}
\end{aligned}
$$

Fig.2に示すようなウェール方向に添った，他の1つは コース方向に添ったこれらの2つの一軸拘束二軸伸長变 形における張力ーUずみ曲線の実測值を張力ー変換ひずみ 直線に直し，実測值のひずみを変換することによって， $C_{i}$ とR $(i=1,2)$ を次式のように得ている.

$$
\begin{aligned}
& C_{1}=F_{1} / e_{1} \\
& C_{2}=F_{2} / e_{2}, \\
& R_{1}=F_{2} / F_{1} \\
& R_{2}=F_{1} / F_{2},
\end{aligned}
$$

これらのパラメータ一定用いて，任意の二軸伸長変形 下での張力Fと変埃ひずみとの関係は次式で計算される。

$$
\begin{aligned}
& F_{1}=S_{22} e_{1} /\left(S_{11} S_{22}-S_{12} S_{21}\right)- \\
& S_{12 \ell_{2}} /\left(S_{11} S_{22}-S_{12} S_{21}\right) \\
& F_{2}=S_{11 e_{2}} /\left(S_{11} S_{22}-S_{12} S_{21}\right)- \\
& S_{21} e_{1} /\left(S_{11} S_{22}-S_{12} S_{21}\right)
\end{aligned}
$$

上式に式 (4-1) ～(4-4)を代入すると,

$$
\begin{aligned}
& F_{1}=C_{1} e_{1}+R_{2} C_{2} e_{2} \\
& F_{2}=R_{1} C_{1} e_{1}+C_{2} e_{2}
\end{aligned}
$$

または，

$$
\left[\begin{array}{l}
F_{1} \\
F_{2}
\end{array}\right]=\left[\begin{array}{ll}
C_{1} & R_{2} C_{2} \\
R_{1} C_{1} & C_{2}
\end{array}\right]\left[\begin{array}{l}
e_{1} \\
e_{2}
\end{array}\right]
$$

と表される。

式（7）または（8）によって，任意の $e_{1} ， e_{2} に お け る F_{1}, F_{2}$

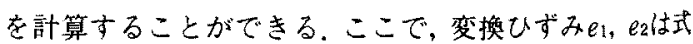
(2)によってひずみ的，致に変換される。

\section{3. 実 験}

\section{1 一軸拘束二軸引張り試験}

川端によって開発されたKES-G2一軸拘束二軸引張り武 験機〔 4 ]を用いて，布の構造主軸にそって一軸を拘束し た二軸伸長特性を測定する，荷重を検出す有有效武料幅 は, $6.4 \mathrm{~cm} \times 6.4 \mathrm{~cm}$ (引張り测定幅 $\times$ 拘束測定幅)，ひずみ

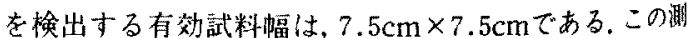
定機により一軸拘束一軸伸長過程における引張り方向と 拘束方向の試料の張力ーひずみ曲線を同時に測定できる。 
引張りひずみ速度 $0.02 / \mathrm{sec} て ゙$, 最大荷重 $250 \mathrm{gf} / \mathrm{cm}$ を繰り 返し 3 回与之た。截維集合体の場合、蕨密に断面積を見 積もることができないため, 張力は变形前の繊維集合体 の单位長さあたりの荷重を張力として定義される。

\section{2 二軸伸長特性}

川端によって試作された二軸引張り試験機を用いて, 布の構造主軸に沿って二軸伸長特性を測定する。交形样

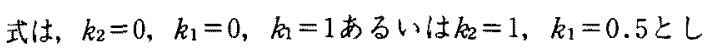
た，一軸拘束二軸伸長特性と同じ塞験条件で，引張りひ

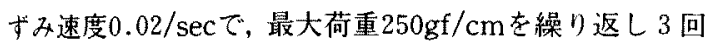
与えた。

\section{3 一軸伸長特性}

KES-G1引張り試験機[5]を用い, 二軸伸長特性と同し実 駼条件で, 引張りひずみ速度 $0.02 / \mathrm{sec}$ で, 最大荷重 $250 \mathrm{gf} /$ $\mathrm{cm}$ 繰り返し 3 回与えた.クランプ部分の拘束をできる だけ少なくした一軸変形を与えるために試料偪 $1.3 \mathrm{~cm}$, 試 料長さ $10 \mathrm{~cm}$ とした。

\section{4 試料}

践維素材，編み組織の異なるパワーネット布を試料と してリニアライジング法の妥当性を検証するために， Table 1(a)に示すように，従来から使用されているポリ ウレタンとナイロン系からなる試料U1，U2と、弾性系と して最近開発されたポりエーテルエステル系弾性系と非 弾性系としてポリエステルフイラメント糸からなる試料 T2を選び，また, Table 1(b)に示すような同じ系使いで， 一般的に用いられている編組織の異なった試料を 3 種選 定した。

Table 1 Details of Samples

\begin{tabular}{|c|c|c|c|c|c|c|}
\hline $\begin{array}{l}\text { Sample } \\
\text { No. }\end{array}$ & Structure & Yam * & $\begin{array}{l}\text { Densit } \\
\text { Wale }\end{array}$ & $\frac{\mathrm{ty}\left(\mathrm{cm}^{-1}\right)}{\text { Cource }}$ & $\begin{array}{l}\text { Weight } \\
\left(\mathrm{g} / \mathrm{m}^{2}\right)\end{array}$ & $\begin{array}{c}\text { Thickness } \\
\text { (mm) }\end{array}$ \\
\hline U! & TR satin & Ny50d x U70 d x U40d & 21 & 80 & 221 & 0.595 \\
\hline U2 & Raschel & Ny50d x U280d & 15 & 69 & 177 & 0.516 \\
\hline$T 2$ & Silfit sation & VSOd $\times R 70 d x R 40 d$ & 21 & 72 & 207 & 0.575 \\
\hline \multicolumn{7}{|l|}{ (b) } \\
\hline $\begin{array}{l}\text { Sample } \\
\text { No. }\end{array}$ & Structure & Yam* & $\frac{\text { Densit }}{\text { Wale }}$ & $\frac{\mathrm{y}\left(\mathrm{cm}^{-1}\right)}{\text { Cource }}$ & $\begin{array}{l}\text { Weight } \\
\left(\mathrm{g} / \mathrm{m}^{2}\right)\end{array}$ & $\begin{array}{l}\text { Thickness } \\
(\mathrm{mm})\end{array}$ \\
\hline W1 & Half net & Ny30d x U280d & 22 & 56 & 201 & 0.617 \\
\hline W2 & Trico aet & $\mathrm{Ny} 30 \mathrm{~d} \times \mathrm{U} 280 \mathrm{~d}$ & 14 & 61 & 165 & 0.556 \\
\hline W3 & 2way raschel & Ny30d x U280d & 22 & 76 & 251 & 0.541 \\
\hline & \multicolumn{2}{|c|}{$\begin{array}{l}\text { V : Cation dyeable PET } \\
\text { R : Polyether/polyester elastic yam }\end{array}$} & \multicolumn{3}{|c|}{$\begin{array}{l}\text { Ny: Nylon } \\
\text { U: Polyurethar }\end{array}$} & Denier \\
\hline
\end{tabular}

\section{4. 結果および考察}

\section{1 一軸狗束二軸伸長特性の線形化}

一軸拘束二軸引張り試験機を用いて測定した一軸拘束 二朝伸長特性の1例をFig.3に示す，従来のリニアライ シンング法では，二軸伸長変形下において，コース方向を 拘束してウェール方向へ伸長する場合 $\log F_{i}-\log \varepsilon_{i}$ お びウェール方向を拘束してコース方向へ伸長する場合

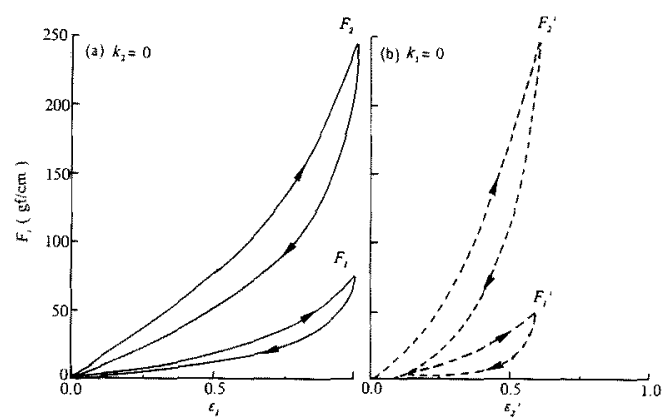

Fig. 3 Stress-strain relations under the strip biaxial extensions along the wale (solid lines) and course (broken lines) directions, under the conditions shown in Fig.2, respectively. (Sample No. U2)

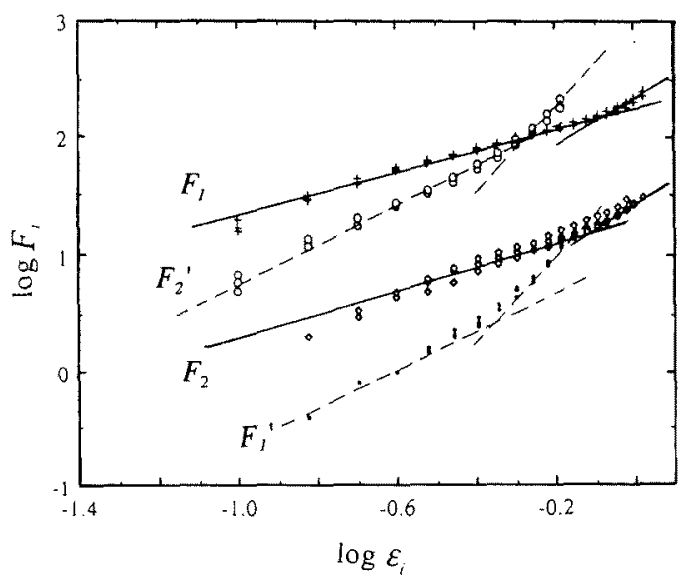

Fig. 4 The logs $F \cdot e$ plot of the stress-strain relations under the strip biaxial extensions along the wale (solid lines) and course (broken lines) directions, respectively. (Sample No. U2)

$\log F_{i}{ }^{\prime}-\log \varepsilon_{i}{ }^{\prime}(i=1,2)$ 曲線の勾配から得られるnがどの ような二軸変形様式においても一定であると仮定されて いるが，ガードル用パワーネットでは，Fig.4に示すよ うにウェール方向引張りとコース方向引張りでは，直線 の公配は明らかに買なっている。パワーネットは2成分 系でその特有の構造のため，変形椂式によって伸長挙動 を大きく異にするため，パワーネット布においてウェー ル方向もしくはコース方向引張りで, 暴なるnをとると 仮定する、すなわち，

$$
\begin{aligned}
& e_{1}=\varepsilon_{1}^{n_{1}} \\
& e_{2}=\varepsilon_{2}{ }^{n_{2}}
\end{aligned}
$$

添字 1 はウェール方向引張り,2はコース方向引張り, $e_{i}(i=1,2)$ は変換ひずみを表す. 
Table 2 Values of mechanical parameters for calculating "biaxial-extension properties"*

(Sample; U1)

\begin{tabular}{llcccccccccc}
\hline & & $n_{3}$ & $y_{1}$ & $y_{2}$ & $n_{2}$ & $y_{2}^{\prime}$ & $y_{1}^{\prime}$ & $C_{2}$ & $C_{2}$ & $R_{1}$ & $R_{2}$ \\
\hline \multirow{2}{*}{ Forward } & Initial Stage & 0.991 & - & - & 1.490 & - & - & 334.9 & 1116.3 & 0.1505 & 0.0531 \\
& Second Stage & - & & & - & & & & & & - \\
\hline \multirow{2}{*}{ Backward } & Initial Stage & 1.003 & 0.536 & 0.523 & 2.205 & - & - & 237.3 & 1561.6 & 0.1166 & 0.0425 \\
& Second Stage & 1.870 & & & - & & & 379.9 & - & 0.1389 & - \\
\hline
\end{tabular}

(Sample; T2)

\begin{tabular}{llcccccccccc}
\hline & & $n_{1}$ & $y_{1}$ & $y_{2}$ & $n_{2}$ & $y_{2}^{\prime}$ & $y_{1}^{\prime}$ & $C_{1}$ & $C_{2}$ & $R_{1}$ & $R_{2}$ \\
\hline \multirow{2}{*}{ Forward } & Initial Stage & 1.079 & - & - & 1.328 & - & - & 474.4 & 715.1 & 0.2387 & 0.0664 \\
& Second Stage & - & & & - & & & - & - & & - \\
\hline \multirow{2}{*}{ Backward } & Initial Stage & 1.291 & 0.403 & 0.430 & 1.748 & 0.378 & 0.378 & 250.9 & 520.9 & 0.3072 & 0.0285 \\
& Second Stage & 2.789 & & & 3.875 & & & 1013.9 & 4089.3 & 0.2534 & 0.0593 \\
\hline
\end{tabular}

*means the extension properties in two main axes under the constant strain on one deformation mode.

Table 3 Values of mechanical parameters for calculating biaxial-extension properties

また，Fig.4からわかるように，2つの異なった傾きを 持つ項域がある。二直線による近似を行った場合は，初 期の勾配と後期の勾配とを区别する。この2つの直線が 交差する点は二軸伸舆変形における布の力学学動の変化 点と考えられる.Table 1の試料布に对して求めたいおよ U゙弾性定数をTable 2,3に示す，nは，n>1なら上に仍 張力ーひずみ曲線を示し， $n=1$ なら弾性体に近い挙動を示

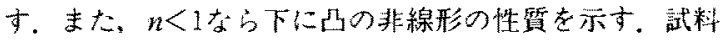
U1は, ウェール万向引張り時, 初期段階ではほ 1 の值を とり，パワーネット布の伸びやすい弾性体に近い性質を 示しているのに对して,ウェール方向引張り時のれに比 べ,コース方向引張り時の $n_{2}$ の方が大きく、これは全般 にコース方向引張り時のちが，伸びにくいことを示して いる。このように，nに伸長特性の特性差が示される。

\section{2 一軸拘束二軸伸長特性からの弾性定数の決定}

Fig.5に $n_{i}(i=1,2)$ を用いて線形化した張力ーひずみ曲線 の1例を示す，実線はウェール方向引張りで，点線はコ 一ス方向引張り特性を表す。図の $F_{5}-e_{i}$ の直線の勾配上り, 弹性定数を決的るパラメーターC $C_{i}, R_{i}$ 方決定される。す なわち， $C_{1}$ は，F $F_{1}-e_{1}$ 直線の勾配， $C_{2}$ は， $F_{2}-e_{2}$ 值線の 勾配， $R_{1}$ は， $C_{1}$ と $F_{2}-e_{1}$ 直線の勾配との比， $R_{2}$ は， $C_{2}$ と $F_{1}$ '- $e_{2}$ '固線の勾配との比である.以上のように布方向别 の $n_{1}, n_{2}$ を用いてリニアライジング法におけるパラメー

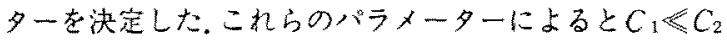
の関係から，パワーネット布はウェール方向引張りに対 し、コース方向引張りが特に伸びにくい性筫を持つこと がわかる。

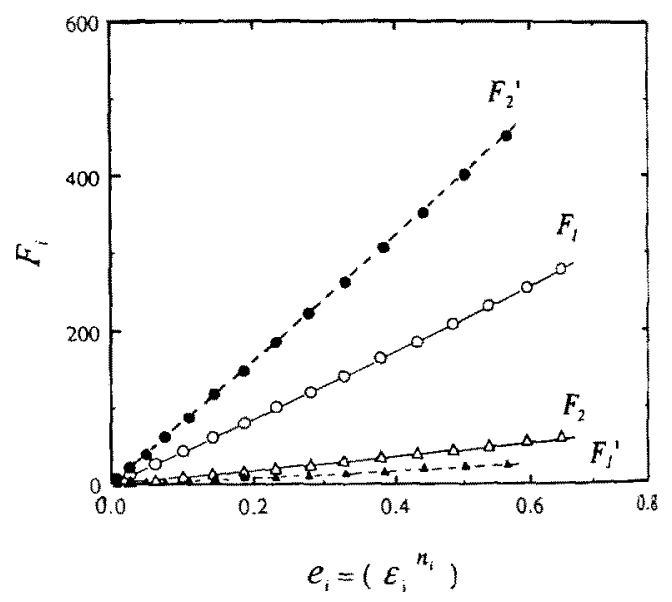

Fig. 5 The linearization of the relation for the strain increasing process. (Sample No. U2)

\section{3 実測値と計算值の比皎}

\subsection{1一軸拘束二軸伸長特性}

実測の張力ーひずみ曲線と、リニアライジンダ法により 得られた予測計算曲線をFig.6, Fig.7に示している。塱( $1,2)$ を $\varepsilon_{i}(i=1,2)$ に逆変換することにより, 予測計算によ る $F_{i}-\varepsilon_{i}(i=1,2)$ の関保が得吕机る，Fig.6は，従来加缏 用されているポリウレタンを用いたU1，Fig.7は，最近閉 発されたポリエーテルエステル系弾性糸を用いたT2の例 である、本論文で定戔したウェール方向引張りと、コー ス方向引張りの $2 つ の n_{1}, n_{2}$ で計算した場合と，従来の 仮定通り、すへての変形樣式でnが一定であるとしてい 


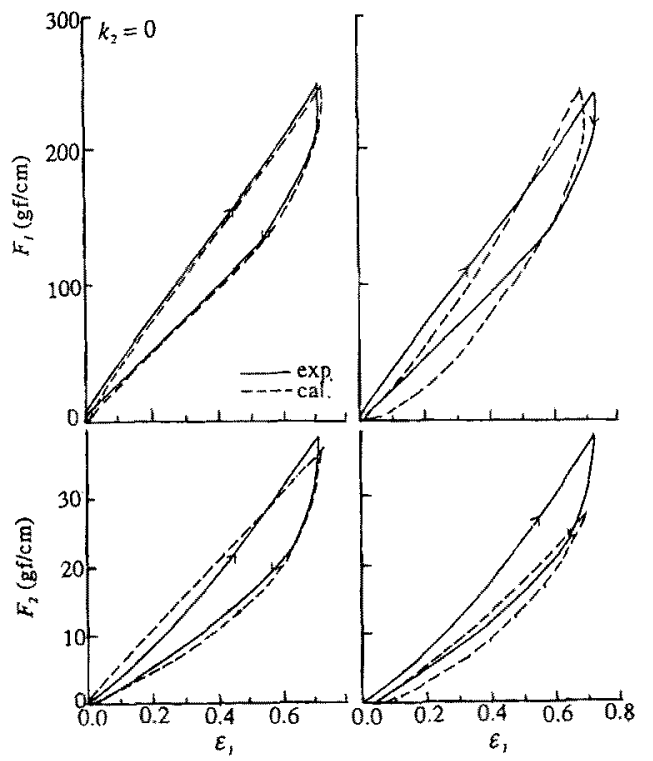

(a)

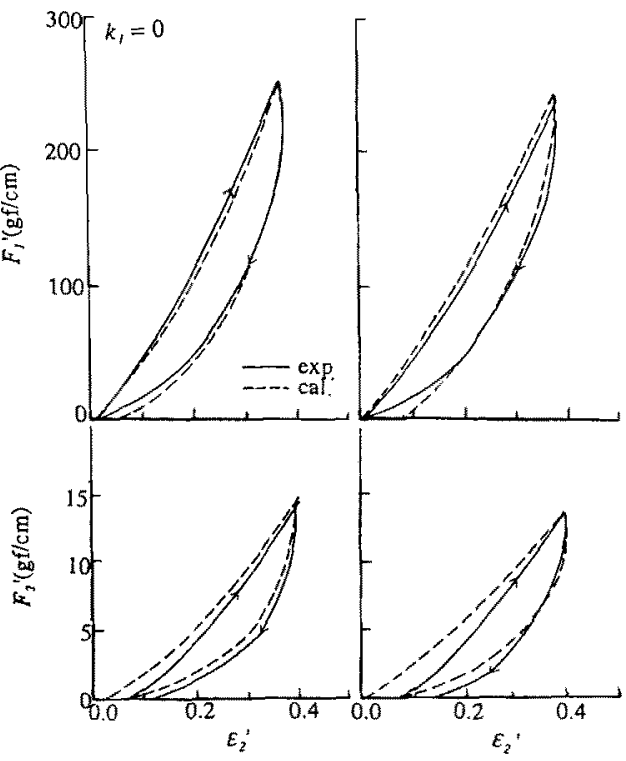

(a)

(b)

Fig. 6 Solid lines: the stress-strain relations observed for sample U1 under the strip biaxial extensions along the wale $\left(k_{2}=0\right)$ and course $\left(k_{1}=0\right)$ directions, respectively. Broken lines: lines calculated by the linearizing method. (a) $n_{i}(i=1,2)$, (b) $n$ (mean of $n_{i}$ $(i=1,2))$.

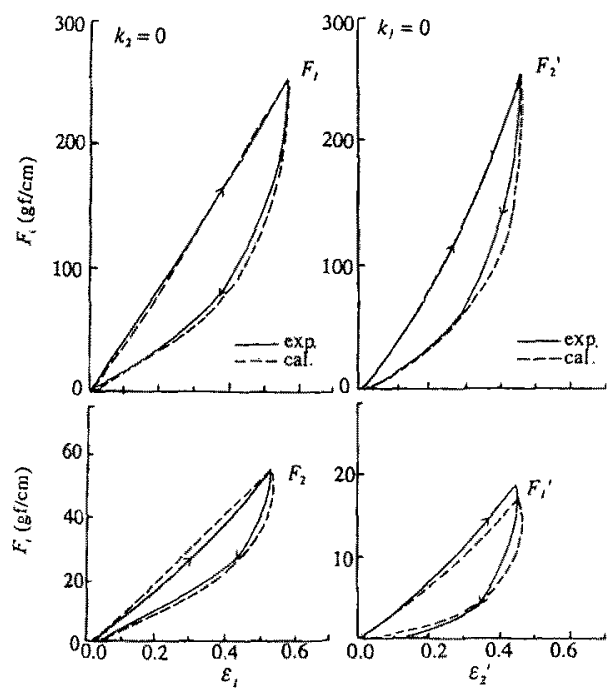

Fig. 7 Solid lines: the stress-strain relationships observed for sample $\mathrm{T} 2$ under the strip biaxial extensions along the wale $\left(k_{2}=0\right)$ and course $\left(k_{1}=0\right)$ directions, respectively. Broken lines: lines calculated by the linearizing method using $n_{i}(i=1,2)$. n を平均した值を用いて計算した場合をFig.6に示して いる. Fig.6からウェール，コース方向別の $n_{1}, n_{2}$ を用い ることで，ウェール，コース方向で大きく伸長特性が暴 なる異方性の特徴をよ人記述するることができ，良好な 一致が確認される。また，二直線近似を行った場合は， 初期およびそれに続く後期の段階それぞれつ籍网におい て張力ーUず网関係を別々に計算し，それぞれの段階の曲 線をなめらかにつなぐことによって，変曲点を含めた張 力ーひずみ曲線を精度主く計算できることがわかる。加之 て，送りの曲線すなわち，伸長回復曲線についても同様 の手順で予測計算を行うことによって龱のように実測曲 線と予測曲線との間に良好な一致が得られた。伸長から の回復曲線については, $n$ よび弾性定数が、伸長過程と 異なり回復過程のをれを一軸拘束二軸伸長特性加ら求为 ておく必要がある。

また，同じ太さのポリウレタン系とナイロン系からな リ，編み組織のみ垶なるTable 1の試料の二軸伸長特性を 記述するパラメーターについても Table 4に示す.同じ系 使いであってもその伸長挙動は大きく異なり，特にコー

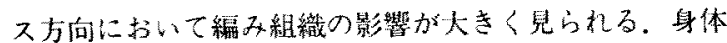
の周径方向に使用され，良く伸ばされるウェール方向引 張り時の実測值と計算值を比較した結果をFig.8に示吉。 


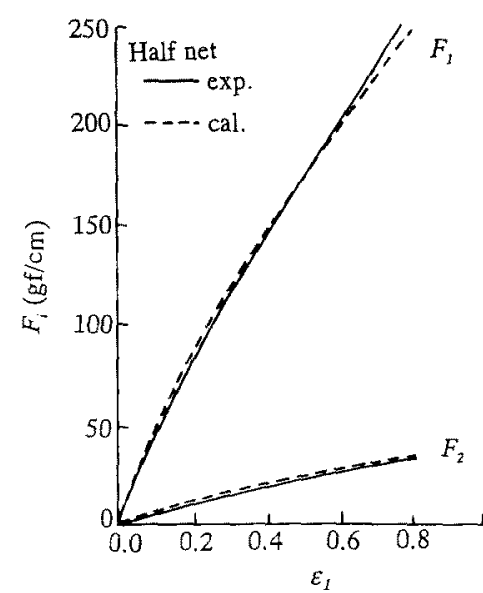

(a) Sample No. W1

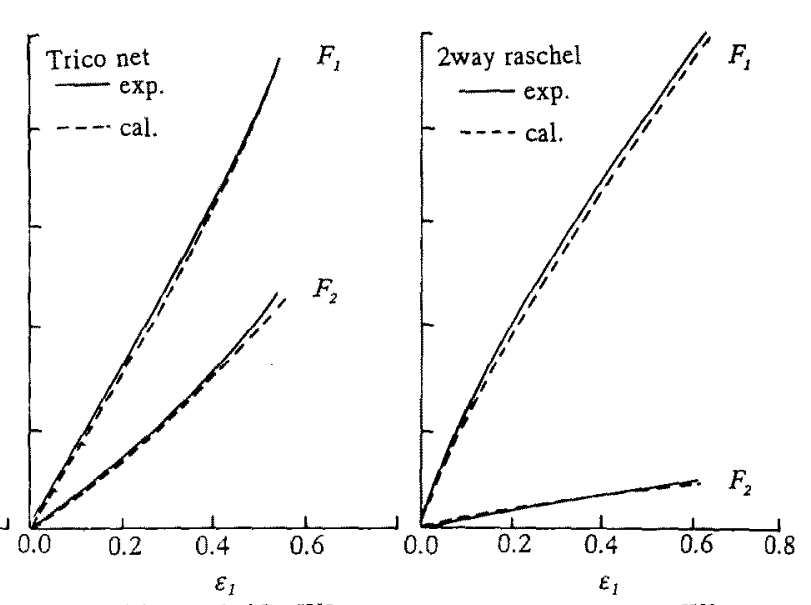

(b) Sample No. W2

(c) Sample No. W3

Fig. 8 Solid lines: the stress-strain relations observed for samples W1, W2, W3 with different structures under the strip biaxial extensions along the wale direction. Broken lines: lines calculated by the linearizing method using $n_{i}(i=1,2)$.

Table 4 Values of mechanical parameters for calculating biaxial-extension properties

\begin{tabular}{lcccccc}
\hline Sample & $n_{1}$ & $n_{2}$ & $C_{2}$ & $C_{2}$ & $R_{3}$ & $R_{2}$ \\
\hline W1 & 0.743 & 1.345 & 289.5 & 526.7 & 0.137 & 0.0854 \\
W2 & 1.239 & 1.168 & 494.7 & 2412.8 & 0.473 & 0.0962 \\
W3 & 0.779 & 1.254 & 364.1 & 572.1 & 0.0929 & 0.0590 \\
\hline \multicolumn{7}{l}{ First cycle, Forward }
\end{tabular}

以上より，編み組織が異なっても実測曲線と計算曲線の 間に良好な一致加確認されな。

\subsection{2 二軸伸莀特性}

二軸伸長特性の代表的な変形样式として，式（1）で定 義した二軸伸長変形梯式 $k_{1}=1$ あるいは $k_{2}=19$ 二軸均等伸 長変形様式の場合，すな⿰ち，ウェ一ルとコース方向に 闰時に等しい伸長ひずみを与えたとき，また， $k_{1}=0.5$ の 二軸伸長変形様式の場合の各方向の張力の寒測曲線と予 测計算曲線とを比較した結果, Fig.9に示すいずれの変形 様式においても実測值と計算值との間に良好な一致がみ られる．以上より任意の变形様式においてりニアライシ ング法による二軸伸長变形時の張力予測の妥当性か確認 きれた。

\subsection{3一軸伸長特性}

一軸拘束二軸伸長特性から求めたりニアライジング法 において，拘束力を零とおいて一軸方向にのみ伸長変形 を与える一軸伸長特性を計算した.Fig.10に示寸実測曲線 と計算曲線は，クランプ部が完全な一軸伸長変形を与え ていないため，やや赛測曲線の方が計算曲線より伸びに
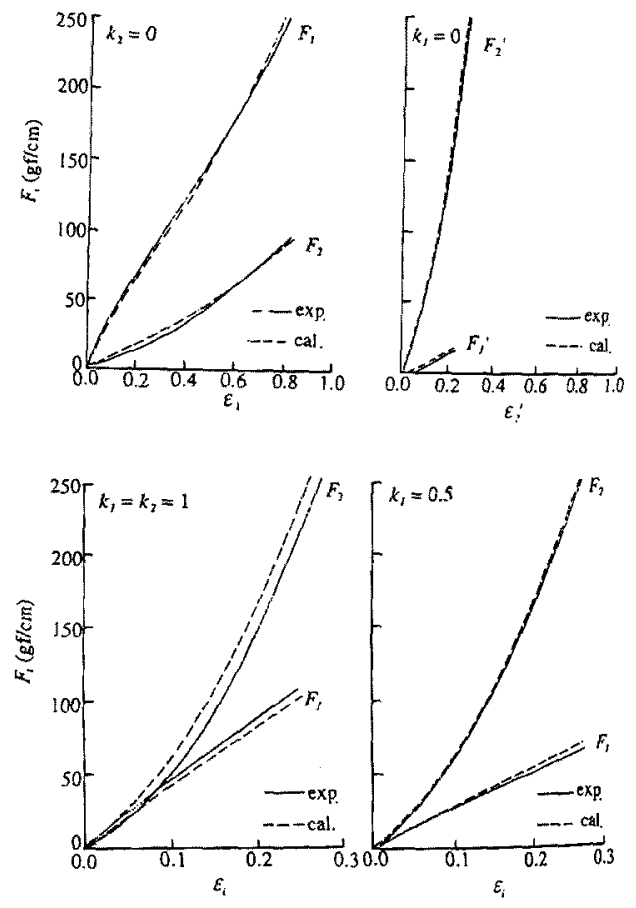

Fig. 9 Broken lines: lines calculated by the linearizing method for $k_{2}=0, k_{1}=0, k=1$ (equal-biaxial) and $k_{1}=0.5$ for sample U2. Solid lines: lines are the experimental curves observed. 


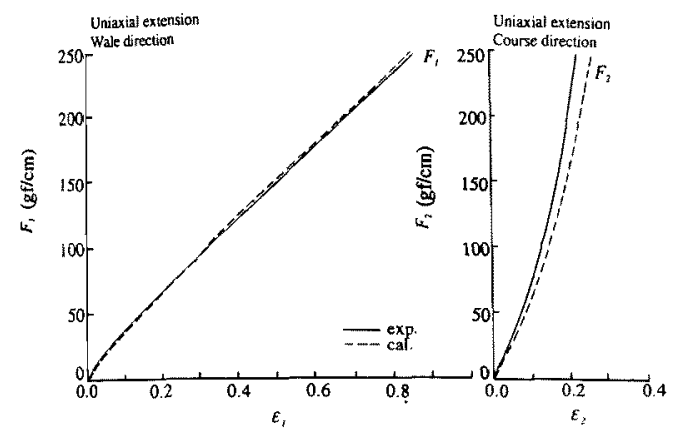

Fig.10 Broken lines: lines calculated by the linearizing method for sample U2 under the uniaxial extensions along the wale and course directions. Solid lines: lines are the experimental curves observed.

くい傾向がみられるものの，両曲線間にはウェール、コ 一ス方向共に良い一致が認められる。 以上より，パワー ネットのような複㒕な瀻維集合構浩をもつ布においても， 既に開発されたりニアライジング法を多少修正して用い ることによって，構造主軸方向へのあらゆる变形様式の 伸辰特性を予測計算できることがわかった。

\section{5. 結 語}

パワーネット布において，構造主軸方向への任意の二 朝伸長ひずみを与えたときの各軸方向の張力を予測する ためのリニアライジング法において，ウェール，コース 方向別に張力ーひずみ曲線を線形関保に变換するための $n_{i}(i=1,2)$ を用いることにより, 二軸均等伸長変形から一 䩜伸長変形までの広範囲の任意の変形様式に対応寸る張 カーひずみ曲線を予測計算できることを明らかにした。
大変形領域において，非線形を線形に变換するための 对数変換を行った張力ーひずみ曲線が，一直線で近似でき ない場合は，二直線で近似を行い，複合する形で実測值 と良好な一致が見られた。

複雑な編み組織や䋐維の種類の異なるパワーネット布 についても，従来のリニアライジング法を方向別の変換 Uずみ $n_{i}(i=1,2)$ を用いることによって，わずかな修正で 二軸伸長变形時の張力子測の妥当性が示された。

\section{謝辞}

本研究を遂行するにあたり，二軸引張り試験機を使わ せていただき，御摡切な御指導をいただきました京都大 学名営教授，現滋賀県立大学川端季雄教授に謝意を表し ます。また，試料の提供および種々のご助言を頂きまし た帝人株式会社, 株式会社ワコール人間科学研究所に謝 意を表します。

\section{文献}

1.川端季雄, 㰇維機械学全誌, 39(11)，169(1986).

2. S. Kawabata, "Textile Structural Composites", Chapter 3 Nonlinear Mechanics of Woven and Knitted Materials, ELSEVIER, 84 (1989).

3. Mari Kageyama, S. Kawabata and Masako Niwa, J. Text. Inst., 79 (4), 543(1988).

4. 川端季雄, 第14回螫維工学研究討論会, 日本䋐維機 械学会, 1(1985).

5. S. Kawabata, "Proceeding of the 4 th Japan-U. S. Conference on Composite Materials at Washington D.C., 1988", A Thechonomic Publishing Company Inc., Lancaster, Penn. U.S.A., 253(1989). 